\title{
TU/e EmonOWEN

\section{Experimental and numerical investigations of a pseudo-2D spout fluidized bed with draft plates}

\section{Citation for published version (APA):}

Sutkar, V. S., Deen, N. G., Salikov, V., Antonyuk, S., Heinrich, S., \& Kuipers, J. A. M. (2015). Experimental and numerical investigations of a pseudo-2D spout fluidized bed with draft plates. Powder Technology, 270(part B), 537-547. https://doi.org/10.1016/j.powtec.2013.11.030, https://doi.org/10.1016/j.powtec.2013.11.030

\section{DOI:}

10.1016/j.powtec.2013.11.030

10.1016/j.powtec.2013.11.030

\section{Document status and date:}

Published: 01/01/2015

\section{Document Version:}

Publisher's PDF, also known as Version of Record (includes final page, issue and volume numbers)

\section{Please check the document version of this publication:}

- A submitted manuscript is the version of the article upon submission and before peer-review. There can be important differences between the submitted version and the official published version of record. People interested in the research are advised to contact the author for the final version of the publication, or visit the $\mathrm{DOI}$ to the publisher's website.

- The final author version and the galley proof are versions of the publication after peer review.

- The final published version features the final layout of the paper including the volume, issue and page numbers.

Link to publication

\section{General rights}

Copyright and moral rights for the publications made accessible in the public portal are retained by the authors and/or other copyright owners and it is a condition of accessing publications that users recognise and abide by the legal requirements associated with these rights.

- Users may download and print one copy of any publication from the public portal for the purpose of private study or research.

- You may not further distribute the material or use it for any profit-making activity or commercial gain

- You may freely distribute the URL identifying the publication in the public portal.

If the publication is distributed under the terms of Article 25fa of the Dutch Copyright Act, indicated by the "Taverne" license above, please follow below link for the End User Agreement:

www.tue.nl/taverne

Take down policy

If you believe that this document breaches copyright please contact us at:

openaccess@tue.nl

providing details and we will investigate your claim. 


\title{
Experimental and numerical investigations of a pseudo-2D spout fluidized bed with draft plates
}

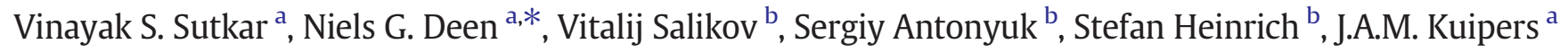 \\ ${ }^{a}$ Multiphase Reactors Group, Department of Chemical Engineering and Chemistry, Eindhoven University of Technology, P.O. Box 513, 5600 MB Eindhoven, The Netherlands \\ ${ }^{\mathrm{b}}$ Institute of Solids Process Engineering and Particle Technology, Hamburg University of Technology, 21071 Hamburg, Germany
}

\section{A R T I C L E I N F O}

Available online 2 December 2013

\section{Keywords:}

Spout fluidized beds

Draft plates

Flow regime map

Particle image velocimetry

Digital image analysis

Discrete particle model and sub grid scale

\begin{abstract}
A B S T R A C T
Spout fluidized beds are often utilized for gas-solid contacting operations involving physical and/or chemical transformations with simultaneous heat and mass transfer such as drying, coating, granulation, combustion, gasification etc. This is because these beds combine advantages of both spouted and fluidized beds. Since the development of the spout fluidized bed, several geometrical modifications have been proposed to optimize the bed performance. One of these modifications often applied in granulation and coating industries includes a draft tube insertion inside the bed, which results in improved performance by providing a restriction on lateral particle flow providing clear distinction for wet spout and dry annulus zones. Moreover, the insertion of the draft tube leads to a stable spouting at lower flow rates, due to the reduced bypassing of the inlet gas (from spout to annulus).

In this work, the hydrodynamic characteristics of a spout fluidized bed with draft plates was studied to identify the flow characteristics by constructing a flow regime map by image analysis and a fast Fourier transform of the measured pressure signal. In addition, the captured images were used to determine the particle velocity via particle image velocimetry (PIV). Furthermore, simulations were carried using a discrete particle model with a sub grid scale turbulence model for two regimes, namely the spouting-with-aeration and fluidized bed-spoutingwith-aeration (dispersed spout), which are of most interest from an industrial view point. The obtained results were compared with previously obtained experimental data i.e. PIV. This study highlights various flow pattern observed during operation of spout fluidized bed with a draft plate over a wider operating conditions, which is useful to select proper operating conditions; whereas the experimental data can be used for computational fluid dynamic (CFD) model validation, which serve as a building block for design and scale-up at higher operational scales. Besides this, the quantitative information such as particle velocity, residence time distribution, solid mixing and circulation can be obtained after suitable post processing hence useful in optimizing the bed performance.
\end{abstract}

(c) 2013 Elsevier B.V. All rights reserved.

\section{Introduction}

Spout fluidized beds are often applied for gas-solid contacting operations involving physical and chemical transformations such as drying, coating, granulation, combustion and gasification. This is because these beds combine features from both spouted and fluidized beds. Moreover, intense gas-solid contact leads to efficient heat and mass exchange. Additionally, spout fluidized beds can be operated for coarse particles with wide size distributions. Since the development of the spout fluidized bed [1], a number of modifications were suggested to improve its performance. These modifications involved different geometrical configurations such as rectangular [2], conical bottom [3,4], slotted rectangular, multiple and elevated spout fluidized beds $[5,6]$. One of the significant modifications includes insertion of a draft tube inside the bed, which results in improved performance by restricting the

\footnotetext{
* Corresponding author.

E-mail address: N.G.Deen@TUe.nl (N.G. Deen).
}

particle cross flow. Moreover, a draft insertion tube results in stable spouting at lower flow rates, due to the reduced bypassing of the inlet gas (from spout to annulus). This is evident from the experimental study on spouted beds with and without draft tube by [7]. They observed a lower minimum spout velocity for a bed with a draft tube, which leads to lower energy consumption to achieve the same spouting characteristics as in a system without a draft tube. Claflin and Fane [8] imply that in conventional spouted beds, particles enter the spout channel from the annulus at various heights, leading to random particle behavior. Furthermore, additional flexibility in the maximum spoutable height without disturbing the stable spouting can be successfully achieved. Additionally, the insertion of a draft tube in a spout fluidized bed provides flexibility to control the particle velocity, bed porosity and gas phase residence time by adjusting operating parameters and geometrical configurations such as the entrainment height and the draft tube dimension.

A detailed understanding of the bed dynamics with flow transition is of primary importance for design and scale-up. This can be either 

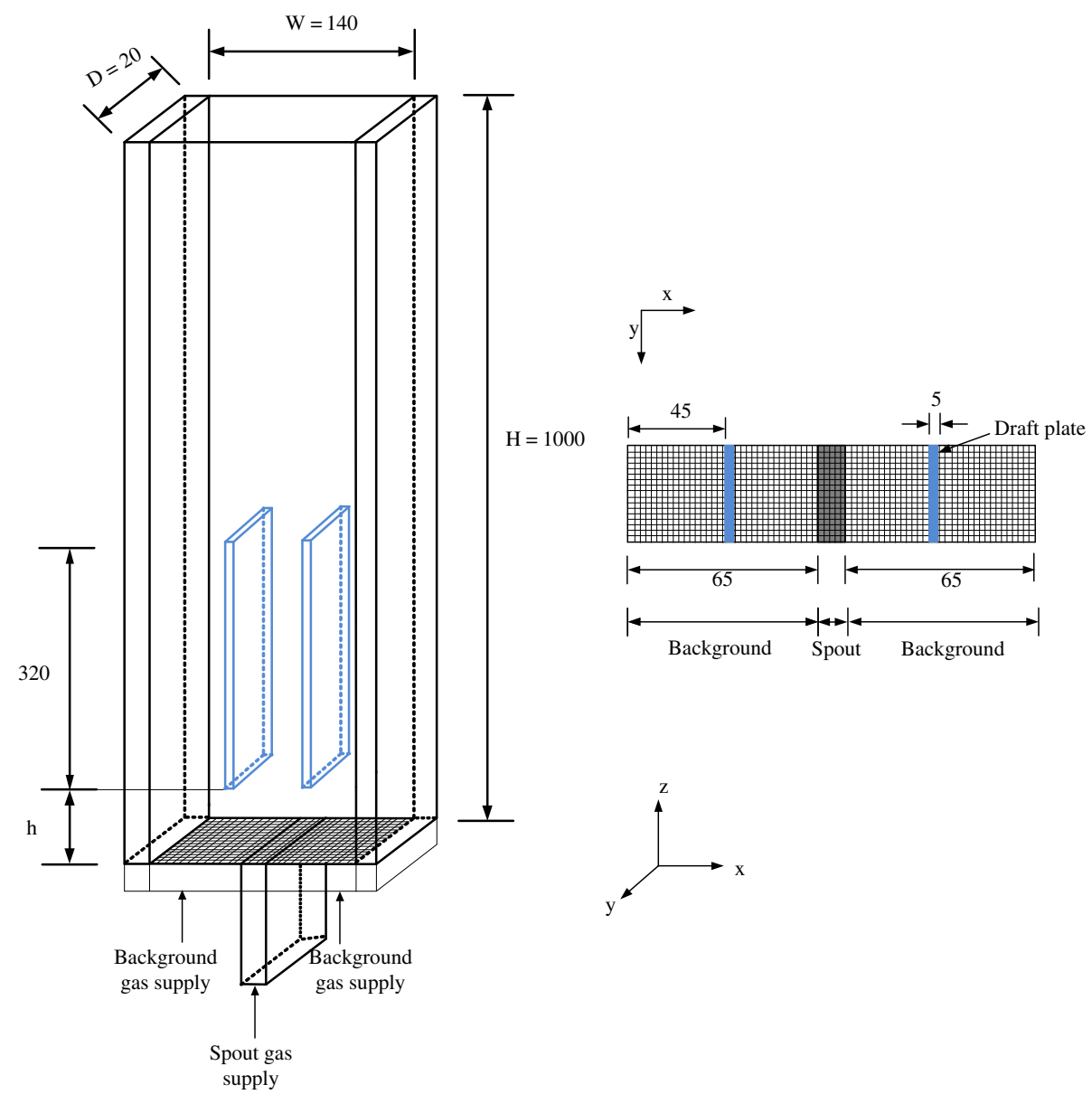

Fig. 1. Schematic representation of a pseudo 2D spout fluidized bed with draft plates with entrainment height (h) (all dimensions in mm).

achieved by performing experiments or simulations. However, it is troublesome to perform the experiments on larger scale, because it is difficult to access the relevant areas experimentally. Over the past few decades, the dynamics of gas-solid systems has been studied using multi-scale simulation approaches [9]. For gas-solid systems, commonly used simulation approaches for laboratory scale contactors are mainly subdivided into two groups viz Eulerian-Lagrangian (discrete model) and the Eulerian-Eulerian approach (continuum model). In both approaches the gas phase dynamics is described by the volume-averaged Navier-Stokes equations. In the Eulerian-Lagrangian approach the motion of the solids phase is obtained by solving Newton's law of motion for individual particle, whereas in the Eulerian-Eulerian approach the solids phase is considered as a continuum. Another promising development involves the use of smooth particle hydrodynamics (SPH) for describing the gas-solid flow in fluidized beds [27]. There exist few studies on dynamics of spout fluidized beds either by the Eulerian-Lagrangian or Eulerian-Eulerian approach. Link et al. [10] performed simulations to study the hydrodynamics of a pseudo 2D spout fluidized bed $\left(\mathrm{W} \times \mathrm{D} \times \mathrm{H}=0.15 \times 0.015 \times 1 \mathrm{~m}^{3}\right)$ by using a discrete particle model (DPM) and validated their results by employing particle image velocimetry (PIV) and digital image analysis (DIA). Link et al. [11]

Table 1

Physical properties of the particles used in the experiments.

\begin{tabular}{llll}
\hline Property & Glass particle & $\gamma$-Aluminum oxide & Unit \\
\hline$d_{p}$ & $1 \pm 0.05$ & $0.9-1.1$ & $\mathrm{~mm}$ \\
$\rho_{p}$ & 2526 & 1040 & $\mathrm{~kg} / \mathrm{m}^{3}$ \\
$u_{m f}$ & 0.64 & 0.33 & $\mathrm{~m} / \mathrm{s}$ \\
$e_{n}$ & 0.97 & 0.74 & - \\
\hline
\end{tabular}

extended these studies to a 3D spout fluidized bed. Furthermore, Link et al. [2] studied the flow characteristics in a 3D spout fluidized bed $\left(\mathrm{W} \times \mathrm{D} \times \mathrm{H}=0.15 \times 0.084 \times 1 \mathrm{~m}^{3}\right.$, with spout dimension of $\left.\mathrm{W} \times \mathrm{D}=0.022 \times 0.012 \mathrm{~m}^{2}\right)$ using positron emission particle tracking (PEPT). They also studied a cylindrical spout fluidized bed $(\mathrm{D}=0.4 \mathrm{~m})$ using a fiber optical probe [12]. Link et al. [13] have reported DPM simulations of a pseudo 2D spout fluidized bed granulator by considering

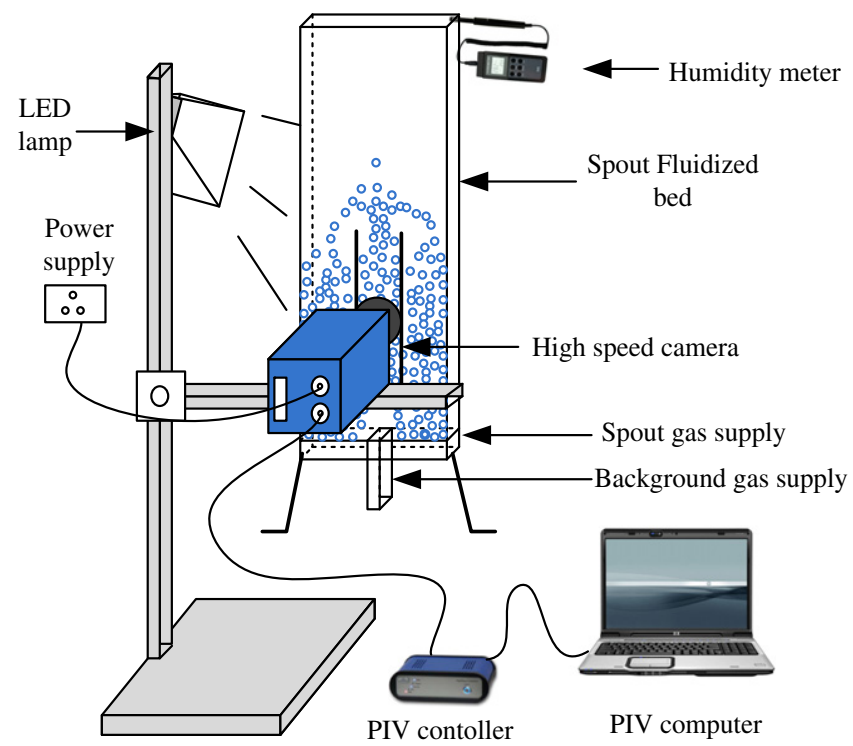

Fig. 2. Schematic representation of PIV setup for spout fluidized bed with draft plates. 
the effect of additional liquid injection. Deng et al. [14] have developed a model to study the coal gasification in a pressurized 3D spout fluidized bed. Zhong et al. [3] numerically studied the hydrodynamics in a rectangular spout fluidized bed using an Eulerian-Lagrangian approach. Zhong et al. [15] have determined the flow patterns in a large scale spout fluidized bed $\left(\mathrm{D} \times \mathrm{H}=1 \times 6 \mathrm{~m}^{2}\right)$ at high pressure and temperature using an Eulerian-Eulerian approach including a turbulence model. Zhang et al. [16] studied the mixing behavior of the particles in a flat bottom spout fluidized bed using an Eulerian-Lagrangian approach, where the turbulence in the gas phase was modeled with a k- $\varepsilon$ model. Van Buijtenen et al. [17] studied the effect of the interparticle interactions on the spout fluidized bed dynamics, by considering different values of the restitution coefficient. This study revealed that a decrease in the restitution coefficient results in the formation of bubbles causes more pronounced heterogeneity (instability) in the overall flow structure of the bed, which significantly depend on the spout and background velocities. In addition, they have performed simulations by extending the DPM to study the effect of inter-particle interaction with a variable restitution coefficient under wet conditions (with additional liquid injection, see [17]). Also, van Buijtenen et al. [18] performed experimental investigations to analyze the effect of variation in the collision properties using three particle types namely glass, $\gamma$-aluminum oxide and zeolite $4 \mathrm{~A}$ on dynamics of a spout fluidized bed.

Even though simulations offer a platform that can be used to obtain better insight, it is necessary to validate the model prediction before the model can be confidently applied for the design and scale-up. The efficacy of the developed model to predict the dynamics of the real system can be achieved by comparing model results with experimental data obtained with non-intrusive techniques. The experimental studies reported in the literature $[6,25]$ generally include the determination of the particle velocity by PIV, PEPT and solid volume fraction by DIA and electrical capacitance tomography (ECT).

The current study aims at constructing a flow regime map for a pseudo 2D spout fluidized bed with a draft tube (from now on we will refer to this as draft plates) with the aid of high speed image analysis and measuring the bed pressure drop. The time-dependent pressure signals were converted into the frequency domain using a Fast Fourier transformation (FFT). Depending on the magnitude of the mean driving frequency and events, identical particulate flow patterns were grouped to form a particular regime, which is designated using the same terminology as reported in [19]. The flow regime map can be used to select proper operating conditions; whereas the experimental data can be used for computational fluid dynamic (CFD) model validation, which serve as a building block for design and scale-up at higher operational scales. Besides this, the quantitative information such as particle velocity, residence time distribution, solid mixing and circulation can be obtained after suitable post processing hence useful in optimizing the bed performance. Moreover, numerical investigations were performed to determine the dynamics of a pseudo 2D spout fluidized bed with draft plates, by considering two regimes, viz. the spouting-withaeration and fluidized bed-spouting-with-aeration (dispersed spout) using a discrete particle model. The obtained results are compared with experimental PIV data.

\section{Experimental investigations}

The dynamics of a spout fluidized bed with draft plates was determined by capturing high speed images, which are utilized for identifying the flow patterns and measuring the particle velocity. In this section, we introduce the experimental setup including brief explanations of the pressure measurement technique and PIV.

\subsection{Experimental set up}

Experiments were conducted in a pseudo 2D spout fluidized bed of dimension $\mathrm{W} \times \mathrm{D} \times \mathrm{H}=0.14 \times 0.02 \times 1 \mathrm{~m}^{3}$, as shown in Fig. 1 with a spout dimension of $\mathrm{W}_{\mathrm{sp}} \times \mathrm{D}_{\mathrm{sp}}=0.01 \times 0.02 \mathrm{~m}^{2}$. The front wall of the bed consists of a glass plate to enable visual observation and the back wall was made of anodized aluminum. Moreover, two draft plates each of dimension $\mathrm{W}_{\mathrm{dt}} \times \mathrm{D}_{\mathrm{dt}} \times \mathrm{H}_{\mathrm{dt}}=0.005 \times 0.02 \times 0.32 \mathrm{~m}^{3}$ were located in the bed at a distance of $0.045 \mathrm{~m}$ from the side wall whereas the entrainment height $(h)$ could be varied in the range of 0.03 to $0.05 \mathrm{~m}$ from the distributor plate. Pressurized air was fed to the bed via three sections at flow rates up to $150 \mathrm{~m}^{3} / \mathrm{h}$. Electrostatic forces between particles were minimized by maintaining the relative humidity of the inlet air approximately equal to $90 \%$. Digital images were recorded using a high speed camera (LaVision Imager pro HS). Reflections occurring during the recording were minimized using LED lamps, illuminating the bed at an angle of $45^{\circ}$. Pressure fluctuations were measured using two pressure sensors located in the spout and annulus. Experiments were performed using two types of particles namely glass and $\gamma$-aluminum oxide. The physical properties are given in Table 1.

\subsection{Pressure measurements}

In this study, pressure measurements were done using sensors located at the backside of the bed, which were connected through a signal convertor to a computer. The signals were recorded for $4 \mathrm{~min}$, with $50 \mathrm{~Hz}$ data acquisition rate. For each inlet flow condition, the images were recorded and measured pressure signals were transformed into an amplitude-frequency domain. The change in the dominant frequency was used as a basis to quantify the flow regime. The obtained results for the pressure fluctuations and FFT distributions are summarized in Table 7.

\subsection{Particle image velocimetry (PIV)}

Particle image velocimetry (PIV) is a non-intrusive measurement technique, which provides information about the average particle displacement. This technique can be used to determine the average particle displacement in pseudo 2D beds. The bed depth is kept sufficiently large to prevent particle bridging from wall.

In PIV, two subsequent images with a small time interval $(\Delta t)$ were captured and subdivided into interrogation areas depending on the available resolution and cross-correlation was applied to determine the volume average particle displacement $\left(\mathbf{s}_{p}\right)$. The particle velocity in each interrogation area is determined by:

$\mathbf{v}_{p}(\mathbf{x}, t)=\frac{\mathbf{s}_{p}}{M \Delta t}$

where $M$ is the image magnification factor and $\Delta t$ is the time interval, which is maintained sufficiently small. During recording, $\Delta t=1 \mathrm{~ms}$ was used and image pairs were recorded at $10 \mathrm{~Hz}$ frequency. The exposure time was adjusted depending on the light intensity and the distance between the camera and the bed. A schematic representation of the PIV setup is shown in Fig. 2. Post-processing was done in DaVis 8.0 .3 , by setting the interrogation area of $64 \times 64$ pixels with $50 \%$ overlap and by applying a geometric mask at the draft plate location. Outliers were removed by using a median filter. For the calculation of the timeaveraged particle velocity fields we used 4000 image pairs.

\section{Numerical investigations}

\subsection{Model equations}

The model equations (Eqs. (2)-(9)) used in this work are summarized in Table 2. For the gas phase we solve the volume-averaged Navier-Stokes equations (Eqs. (2) and (3)), whereas for each of the particles we solve the equations of motion (Eqs. (6)-(8)). 
Table 2

Model equations used for numerical investigations of spout fluidized bed.

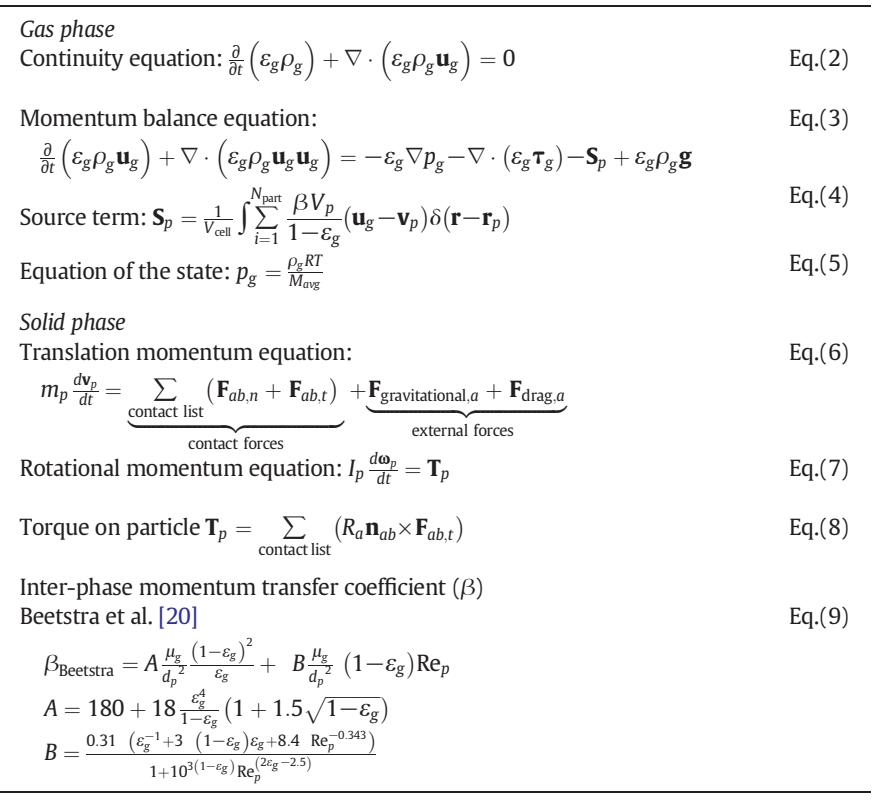

The turbulence generated by the high velocity spout was modeled using the sub-grid scale (SGS) turbulence model proposed in [21]. This model can handle both transitional and turbulent flow, in the vicinity of walls. Also, this model does not involve explicit filtering, averaging or other clipping procedures. The shear induced turbulent viscosity in this model is given by:

$\mu_{\text {tur }}=c \rho_{g} \sqrt{\frac{B_{\beta}}{\alpha_{i j} \alpha_{i j}}}=2.5 C_{s}^{2} \rho_{g} \sqrt{\frac{B_{\beta}}{\alpha_{i j} \alpha_{i j}}}$

$$
\begin{aligned}
& B_{\beta}=\beta_{11} \beta_{22}-\beta_{12}^{2}+\beta_{11} \beta_{33}-\beta_{13}^{2}+\beta_{22} \beta_{33}-\beta_{23}^{2} \\
& \beta_{i j}=\Delta_{m}^{2} \alpha_{m i} \alpha_{m j} \\
& \alpha_{i j}=\partial_{i} u_{j}=\frac{\partial u_{j}}{\partial x_{i}}
\end{aligned}
$$

here $\Delta_{\mathrm{m}}$ is the local filter width. The model constant $c$ is related to the Smagorinsky constant $C_{s}$ ([22]) by: $c \approx 2.5 C_{s}^{2}$. The symbol $\alpha$ stands for the $(3 \times 3)$ matrix of the derivatives of the filtered velocity $\mathbf{u}_{\mathrm{g}}$.

\subsection{Inter-phase coupling and internal wall treatment}

A proper selection of the Eulerian grid size and the associated function to map parameters between the Eulerian grid and the Lagrangian particle positions is of key importance in DPM simulations. Transfer of properties between the Eulerian and Lagrangian positions can be achieved by mapping functions as described in more detail in [23-25].

In this study, the simulations were carried by considering an approach proposed in [25]. In this approach, each particle is represented by a porous cube, with a size equal to, where ' $a$ ' is the ratio of cube diameter to particle diameter. During this study, simulations were carried for

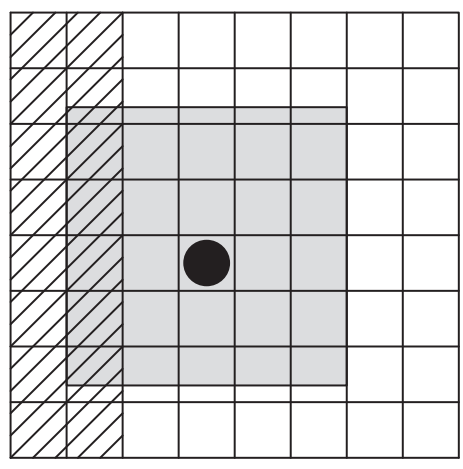

Regular mapping cube

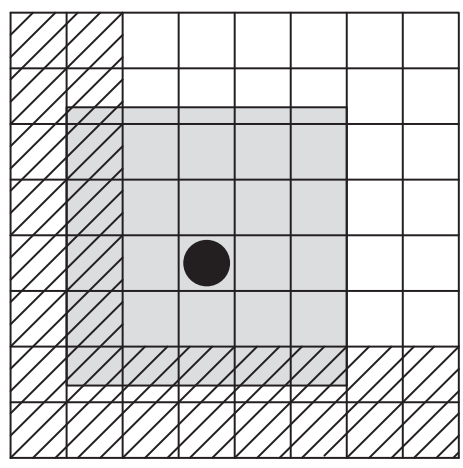

Regular mapping cube

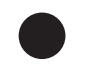

Particle

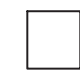

Flow cell

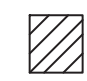

Wall cell

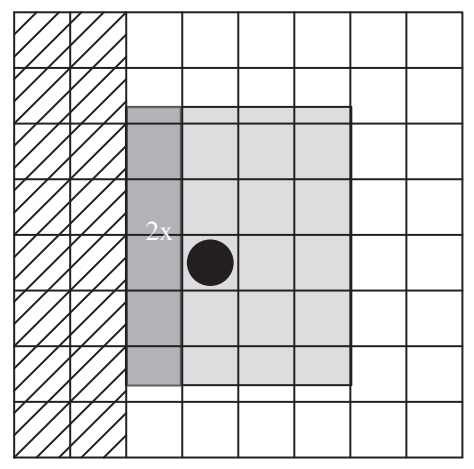

Folded mapping cube

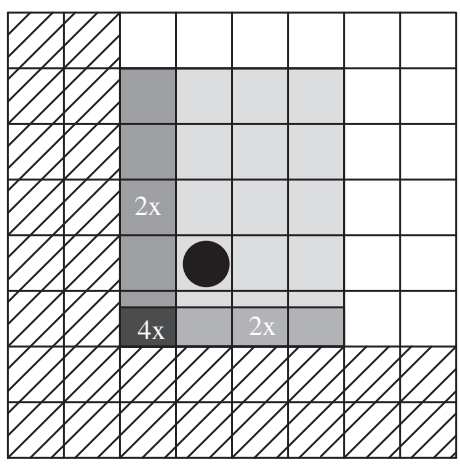

Folded mapping cube

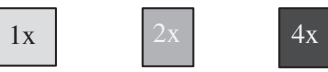

Weighing factor

Fig. 3. Representation of the mapping window at the boundaries of the computational domain. 


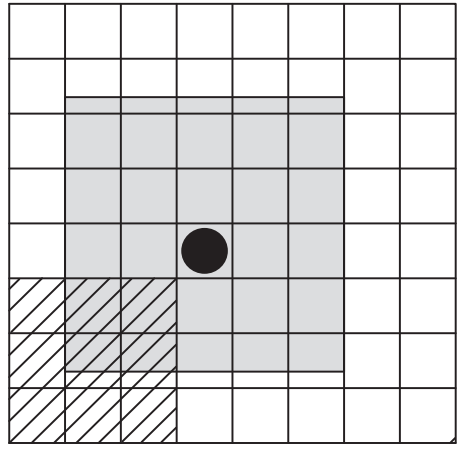

Regular mapping cube

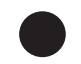

Particle

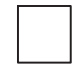

Flow cell

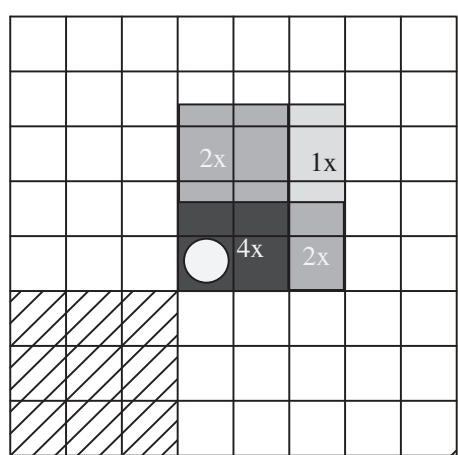

Folded mapping cube

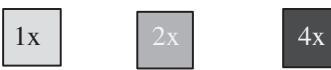

Weighing factor

Fig. 4. Representation of the mapping window near the corner of an internal wall.

mapping window of size equal to 5 times the particle diameter. The porosity of the cube can be calculated from:

$\varepsilon_{\text {cube }}=\frac{V_{p}}{V_{\text {cube }}}=\frac{\pi}{6 \mathrm{a}^{3}}$.

In general, variables from the Eulerian grid $\left(\phi_{E}\right)$ are mapped to the Lagrangian positions $\left(\phi_{L}\right)$ and vice versa using:

$\phi_{E}=V_{\text {cell }} \sum_{\forall} \frac{f_{\text {cell }}^{i} \phi_{L}}{V_{i}}$

$\phi_{L}=\frac{1}{V_{\text {cube }}} \sum_{j} f_{j}^{\text {cube }} V_{j} \phi_{E}$

$f_{j}^{\text {cube }}$ is the volume fraction of cell $j$ occupied by the cube and $f_{\text {cell }}^{i}$ is the volume fraction of cell $i$ occupied by the cube. For particles close to a wall the mapping function is folded back into the simulation domain, as illustrated in Fig. 3. For the simulation of a spout fluidized bed with draft plates, a similar approach as proposed by [25] has been applied for the internal walls. However, cells in the vicinity of corners of internal walls are folded around both walls, as illustrated in Fig. 4.

Internal walls inside the bed are defined using a flag matrix concept, which offers the flexibility to define different boundary conditions by assigning a specific value to the cell flag. These cell flags were associated with relevant information about the boundary condition. More information about the flag matrix concept can be found in [23].

In this simulation, no-slip boundary conditions were defined for internal walls by setting the tangential velocity inside the wall equal to that outside the wall, however with an opposite sign. Furthermore,

Table 3

Cell flag values for the boundary conditions.

\begin{tabular}{ll}
\hline $\mathrm{Fl}(\mathrm{i}, \mathrm{j}, \mathrm{k})$ & Type of cell \\
\hline 1 & Interior cell, no boundary conditions to be specified \\
2 & Symmetry boundary condition, free slip boundaries \\
3 & Impermeable wall, no-slip boundaries \\
4 & Fluid phase influx cell, velocities have to be specified \\
5 & Prescribed pressure cell, free slip boundaries \\
6 & Continuous outflow cell, free slip boundaries \\
7 & Corner cell, no boundary conditions have to be specified \\
8 & Internal wall, no slip boundaries \\
\hline
\end{tabular}

collisions between the particles and an internal wall were treated in the same manner as those with external walls. Collisions of particles on a corner of an internal wall were treated on the basis of the particle center of mass. A particle with its center of mass below the diagonal line will collide with the side surface of the wall, whereas a particle with its center of mass above the diagonal line will collide with the top surface.

An overview of various boundary conditions used in DPM simulations can be found in Table 3. In this study the simulations were performed by applying the no-slip conditions at the side walls, whereas the bottom wall was set as an inflow boundary. The draft plates were modeled as internal walls with no-slip conditions. Fig. 5 illustrates the boundary conditions used in our simulations.

\subsection{Test cases}

Simulations were performed for a pseudo 2D spout fluidized bed shown in Fig. 1. We varied the spout and background velocities and

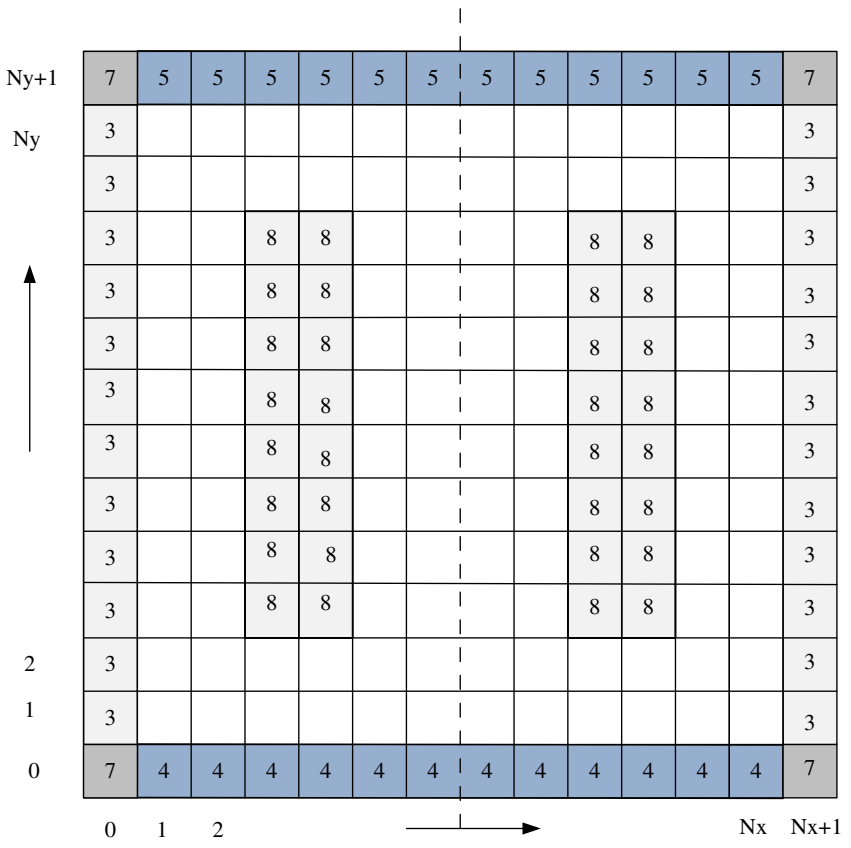

Fig. 5. Boundary condition implemented using flag matrix concept. 
Table 4

Designated of various flow regimes.

\begin{tabular}{lll}
\hline Case & Description & Particles \\
\hline B1 & Spouting-with-aeration & Glass \\
B2 & Fluidized bed-spouting-with-aeration (dispersed spout) & Glass \\
B3 & Spouting-with-aeration & $\gamma$-Aluminum oxide \\
B4 & Fluidized bed-spouting-with-aeration (dispersed spout) & $\gamma$-Aluminum oxide \\
\hline
\end{tabular}

physical properties of the particles. The different simulation cases are summarized in Tables 4 and 5. The cases B1 and B2 were performed using glass particles, whereas in cases B3 and B4 $\gamma$-aluminum oxide was used. The settings used in the simulations are listed in Table 6.

\section{Results}

\subsection{Establishment of a flow regime map}

For construction of the flow regime map, the experiments were performed by varying the background velocity from 0 to $1.75 \mathrm{~m} / \mathrm{s}$ with increments of $0.25 \mathrm{~m} / \mathrm{s}$ whereas the spout velocity was varied from 10 to $50 \mathrm{~m} / \mathrm{s}$ with increments of $5 \mathrm{~m} / \mathrm{s}$. Based on the high speed image analysis, pressure drop measurements and its frequency spectrum eight distinct flow regimes were identified. It should be noted that it is difficult to evaluate the transition between the regimes solely using the image analysis. Critical values of $u_{b g} / u_{u m f}$ and $\mathrm{u}_{\mathrm{sp}} / \mathrm{u}_{\mathrm{umf}}$ for certain regimes were determined by spectral analysis, which are summarized in Table 7. Additionally, the regimes with small differences in the FFT spectrum were analyzed visually and on the basis of variation in the pressure drop. The eight distinct flow regimes based on the above criteria were grouped to form a flow regime map, as shown in Fig. 6, displaying a characteristic snapshot for each identified regime.

We investigated the effect of particles properties with two particle types. In this section, the results for the spouting-with-aeration regime and the fluidized bed-spouting-with-aeration (dispersed spout) regime are presented, both for glass and $\gamma$-aluminum oxide particles. It is noted that the simulations for different particle types were carried by keeping the values of $\mathrm{u}_{\mathrm{sp}} / \mathrm{u}_{\mathrm{mf}}$ and $\mathrm{u}_{\mathrm{bg}} / \mathrm{u}_{\mathrm{mf}}$ constant.

In this section, the observed flow patterns will be discussed in more detail. In addition to this, time-averaged particle velocities in the vertical direction $\left\langle\mathrm{v}_{p, z}\right\rangle$ was quantified at various heights and compared with experimental data.

Table 5

Physical properties of gas and particles and numerical settings.

\begin{tabular}{llllll}
\hline $\begin{array}{l}\text { Parameters/ } \\
\text { case }\end{array}$ & B1 & B2 & B3 & B4 & Unit \\
\hline Material & Glass & Glass & $\begin{array}{l}\gamma \text {-Aluminum } \\
\text { oxide }\end{array}$ & $\begin{array}{l}\gamma \text {-Aluminum } \\
\text { oxide }\end{array}$ & - \\
$d_{p}$ & 1 & 1 & 1 & 1 & $\mathrm{~mm}$ \\
$\rho_{p}$ & 2526 & 2526 & 1040 & 1040 & $\mathrm{~kg} / \mathrm{m}^{3}$ \\
$e_{n, p} \rightarrow p$ & 0.97 & 0.97 & 0.74 & 0.74 & - \\
$e_{n, p} \rightarrow w$ & 0.97 & 0.97 & 0.74 & 0.74 & - \\
$e_{t, p} \rightarrow p$ & 0.33 & 0.33 & 0.1 & 0.1 & - \\
$e_{t, p} \rightarrow w$ & 0.33 & 0.33 & 0.1 & 0.1 & - \\
$\mu_{p} \rightarrow p$ & 0.1 & 0.1 & 0.1 & 0.1 & - \\
$\mu_{p \rightarrow w}$ & 0.1 & 0.1 & 0.1 & 0.1 & - \\
$N_{p}$ & 461,443 & 461,443 & 461,443 & 461,443 & - \\
$u_{b g}$ & 0.32 & 0.81 & 0.17 & 0.43 & $\mathrm{~m} / \mathrm{s}$ \\
$u_{b g} / u_{m f}$ & 0.5 & 1.275 & 0.5 & 1.275 & - \\
$u_{s p}$ & 28.4 & 23.5 & 15.08 & 12.5 & $\mathrm{~m} / \mathrm{s}$ \\
$u_{s p} / u_{m f}$ & 44.37 & 37.00 & 44.37 & 37.00 & - \\
$\rho_{g}$ & 1.2 & 1.2 & 1.2 & 1.2 & $\mathrm{~kg} / \mathrm{m}^{3}$ \\
$\mu_{g}$ & $1.8 \times 10^{-5}$ & $1.8 \times 10^{-5}$ & $1.8 \times 10^{-5}$ & $1.8 \times 10^{-5}$ & $\mathrm{~kg} / \mathrm{m} \mathrm{s}$ \\
\hline
\end{tabular}

Table 6

Parameter values used in the simulations.

\begin{tabular}{lll}
\hline Parameter & Value & Unit \\
\hline$\Delta \mathrm{x}, \Delta \mathrm{y}, \Delta \mathrm{z}$ & $2.5 \times 10^{-3}$ & $\mathrm{~m}$ \\
$\Delta t_{g}$ & $1.5 \times 10^{-5}$ & $\mathrm{~s}$ \\
$\Delta t_{p}$ & $3 \times 10^{-6}$ & $\mathrm{~s}$ \\
$k_{n}$ & $1.1 \times 10^{4}$ & $\mathrm{~N} / \mathrm{m}$ \\
$k_{t}$ & $3.1 \times 10^{3}$ & $\mathrm{~N} / \mathrm{m}$ \\
\hline
\end{tabular}

\subsection{Spouting-with-aeration}

In this regime, a stable spouting was observed in the spout with random particle movement in the annulus, which can be seen from Figs. 7 and 8 respectively for the glass and $\gamma$-aluminum oxide particles. With increasing spout velocity, the particles in the spout, after reaching the zone above the draft plates move in the lateral direction, lose their momentum and fall down in the annulus. Now we will discuss the particulate flow behavior for both particle types.

\subsubsection{Glass particles (B1)}

With increasing spout velocity, particles present near the distribution plate are accelerated upwards through the draft plates up to a certain height, without pronounced cluster formation. After reaching a certain height, particles move laterally and subsequently lose their momentum and move down into the annulus. This continuous upward and downward transport of the particles leads to steady particle circulation patterns, with relatively high particle velocities inside the draft plates. Fig. 7(a-c) shows images from the experiments for the spouting-with-aeration regime, illustrating non-uniform particle distribution between the left and right compartment of the bed. This nonuniformity primarily depends on the extent of gas bypassing during the experiments, initial amount of particles in the annulus and generation of the spout. During the experiments, it was observed that the gas emerging from the spout frequently diverted towards the right side withdrawing and transporting a larger number of particles from the right annulus section.

Table 7

Characterization criteria for identifications of the flow regimes.

\begin{tabular}{|c|c|c|c|}
\hline No. & Regime & Frequency variation & Pressure variation \\
\hline I & $\begin{array}{l}\text { Intermittent } \\
\text { spouting }\end{array}$ & $\begin{array}{l}\text { A moderate power } \\
\text { distribution with a dominant } \\
\text { frequency peak at } 6-7 \mathrm{~Hz} \\
\text { and low power peaks at } \\
12-13 \mathrm{~Hz}\end{array}$ & $\begin{array}{l}\text { A periodic variation in the } \\
\text { pressure signals with high } \\
\text { and low magnitude }\end{array}$ \\
\hline II & $\begin{array}{l}\text { Spouting-with- } \\
\text { aeration } \\
\text { (aggregative } \\
\text { spout); }\end{array}$ & $\begin{array}{l}\text { A low power distribution } \\
\text { without any dominant } \\
\text { frequency peak }\end{array}$ & $\begin{array}{l}\text { A small change in the } \\
\text { pressure signals with } \\
\text { periodic high magnitude } \\
\text { pressure pulses }\end{array}$ \\
\hline III & $\begin{array}{l}\text { Spouting-with- } \\
\text { aeration }\end{array}$ & $\begin{array}{l}\text { Very low power distribution } \\
\text { without any significant } \\
\text { frequency peak }\end{array}$ & $\begin{array}{l}\text { A very small change in the } \\
\text { pressure signals without } \\
\text { any pressure pulses }\end{array}$ \\
\hline IV & Fluidized bed & $\begin{array}{l}\text { A moderate power } \\
\text { distribution with a dominant } \\
\text { frequency at } 1.25 \mathrm{~Hz}\end{array}$ & $\begin{array}{l}\text { A periodic variation in the } \\
\text { pressure signals with some } \\
\text { fluctuations }\end{array}$ \\
\hline V & $\begin{array}{l}\text { Fluidized bed } \\
\text { (spout slugging) }\end{array}$ & $\begin{array}{l}\text { A high power distribution } \\
\text { with wider variation and a } \\
\text { dominant frequency at } \\
1.25 \mathrm{~Hz}\end{array}$ & $\begin{array}{l}\text { A periodic variation in the } \\
\text { very high and low } \\
\text { magnitude pressure signals }\end{array}$ \\
\hline VI & $\begin{array}{l}\text { Fluidized bed- } \\
\text { spouting-with- } \\
\text { aeration (aggrega- } \\
\text { tive spout) }\end{array}$ & $\begin{array}{l}\text { A wider distribution of the } \\
\text { moderate power, without } \\
\text { any frequency peak }\end{array}$ & $\begin{array}{l}\text { A periodic variation in the } \\
\text { pressure signals in a chaotic } \\
\text { fashion }\end{array}$ \\
\hline VII & $\begin{array}{l}\text { Fluidized bed- } \\
\text { spouting-with- } \\
\text { aeration } \\
\text { (dispersed spout). }\end{array}$ & $\begin{array}{l}\text { A wider power distribution } \\
\text { with two dominant } \\
\text { frequency at } 0.5 \text { and } 1.5 \mathrm{~Hz}\end{array}$ & $\begin{array}{l}\text { A periodic variation in the } \\
\text { pressure signals with some } \\
\text { irregular behavior }\end{array}$ \\
\hline
\end{tabular}




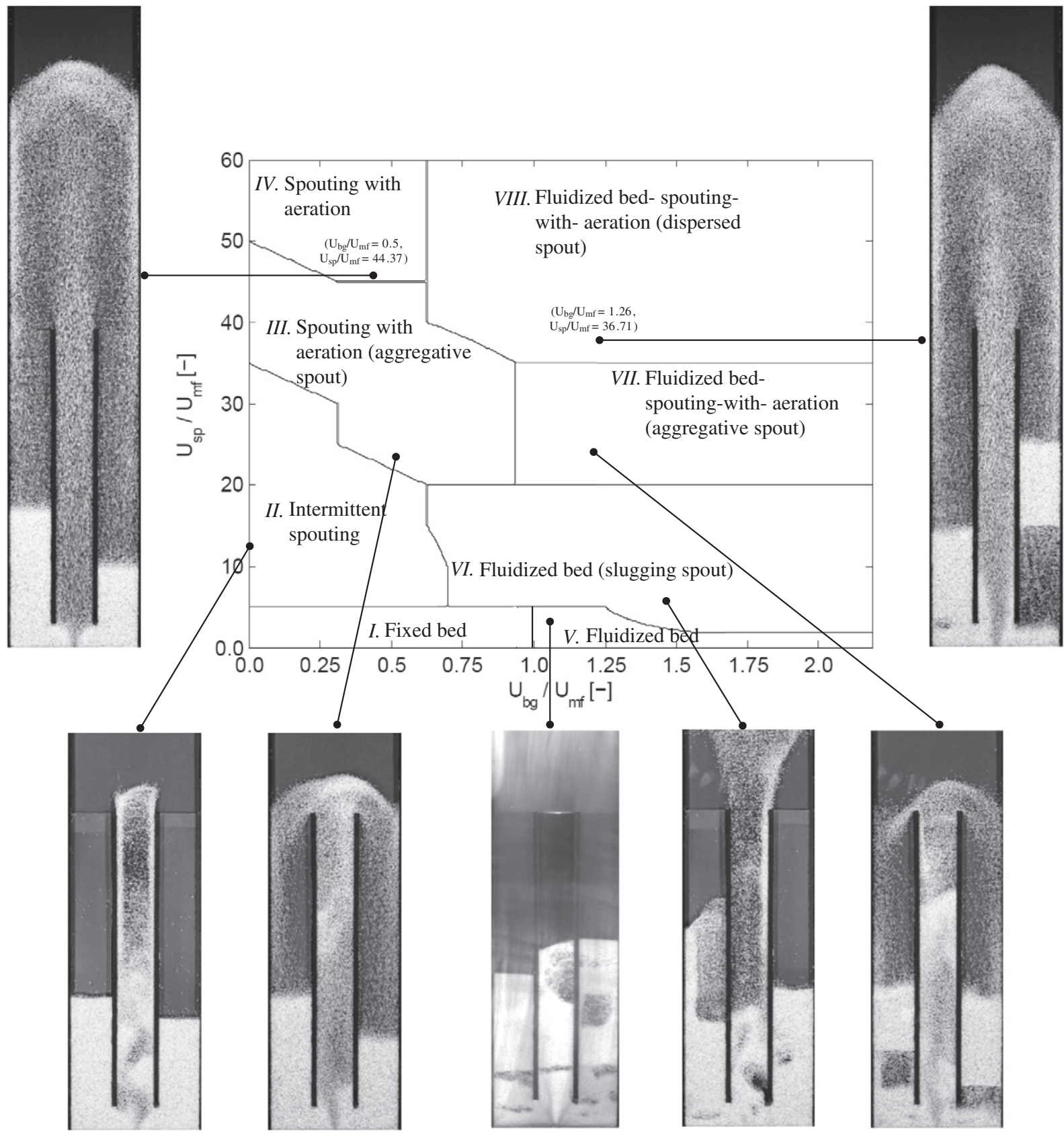

Fig. 6. Flow regime map for a glass particles in a spout fluidized bed with an entrainment height of $h=0.03 \mathrm{~m}$, and a static bed aspect ratio of $H_{0} / W=1$.

Similar circulatory behavior was observed during simulations (see Fig. 7(d-g)). However, during the simulations more homogenous particle distributions were observed in the annulus as compared with the experimental findings. This is because the particles near the distribution plate offers uniform static load on incoming gas, without any deviation in the spout. But, after reaching a quasi-steady condition (at simulation time $t=7.5 \mathrm{~s}$ ) non-uniformity in the particle distribution can be clearly seen from Fig. $7 \mathrm{~g}$.

\subsection{2. $\gamma$-Aluminum oxide particles (B3)}

For the $\gamma$-aluminum oxide particles, similar circulation patterns were observed as for the glass particles. Fig. $8(\mathrm{a}-\mathrm{c})$ and $(\mathrm{d}-\mathrm{g})$ shows snapshots obtained from the experiments and the simulation respectively. From these snapshots the formation of particle clusters inside the draft plates can clearly be seen. In addition meandering of the spout inside the draft plates is observed. Also, $\gamma$-aluminum oxide particles were transported to a lower height compared to glass particles, despite of the same $\mathrm{u}_{\mathrm{sp}} / \mathrm{u}_{\mathrm{mf}}$ and $\mathrm{u}_{\mathrm{bg}} / \mathrm{u}_{\mathrm{mf}}$. This is due to the differences in the physical properties of particles especially, the restitution coefficient. The particles with a lower coefficient of restitution promote the dense regions formation, mainly in the form of clusters with more pronounced energy dissipation during particle-particle collisions. In this regime, the spout velocity was not sufficient to lift the formed particle clusters. Hence, the periodic formation and collapse of the particle clusters was observed inside the draft plates. This leads to a lower exchange rate of particles between the zone inside the draft plates and the annulus. In addition, the formed clusters partially block the draft plates encouraging unsteady pulsating particulate flow patterns with reduced bed height. During the simulations, an equal particle distribution on both sides of the draft plates was observed, which is in contrast with the experimental observations. 


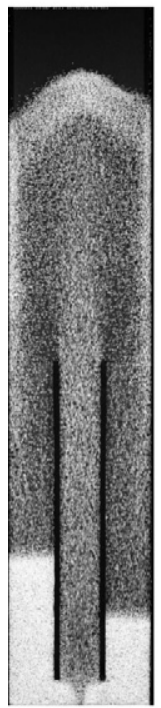

(a) $t=1 s$

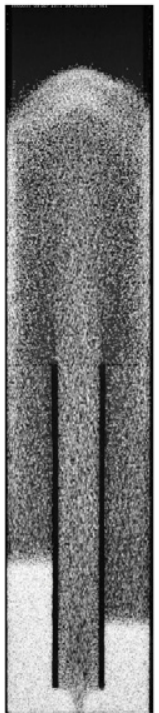

(b) $\mathrm{t}=2.5 \mathrm{~s}$

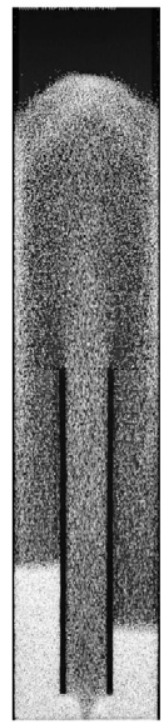

(c) $\mathrm{t}=3.5 \mathrm{~s}$

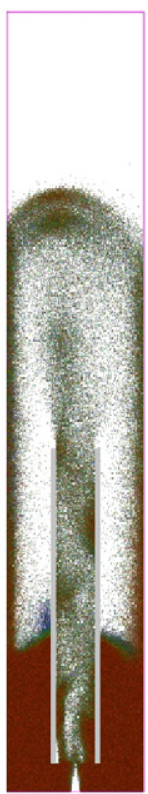

(d) $t=1 s$

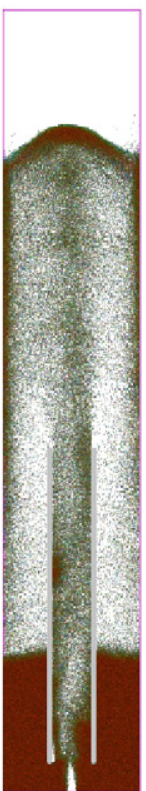

(e) $t=2 s$

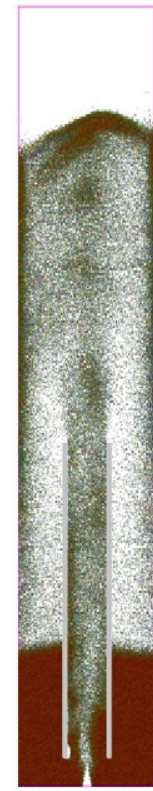

(f) $t=3 s$

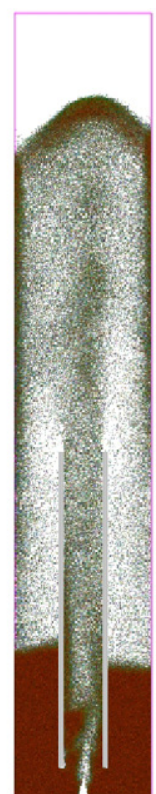

(g) $t=7.5 \mathrm{~s}$

Fig. 7. Snapshots of spouting-with-aeration regime in a spout fluidized bed (a-c) experimental and (d-g) simulation results for glass particles (case B1).

\subsection{Fluidized bed-spouting-with-aeration (dispersed spout)}

In the fluidized bed-spouting-with-aeration (dispersed spout) regime, the particles in the draft plates were elevated to a larger height as compared with the spouting-with-aeration regime, due to the higher background velocities with considerable displacement in the annulus. The total system operates like a circulating bed. Snapshots obtained during the experiments and simulations are shown in Figs. 9 and 10 for glass and $\gamma$-aluminum oxide particles respectively.

\subsubsection{Glass particles (B2)}

Fig. 9(d-g) displays a series of snapshots of a simulation of a spout fluidized bed in the fluidized bed-spouting-with-aeration regime using glass particles. Contrary to the experiments (Fig. $9(\mathrm{a}-\mathrm{c})$ ) in the

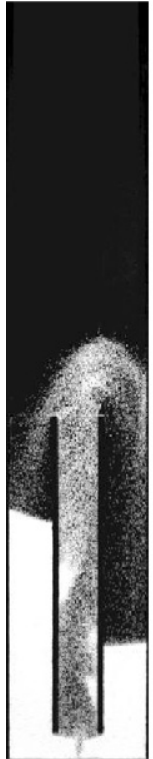

(a) $\mathrm{t}=1 \mathrm{~s}$

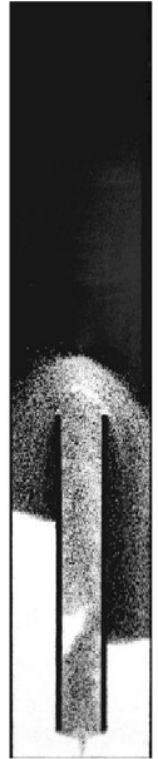

(b) $\mathrm{t}=2.5 \mathrm{~s}$

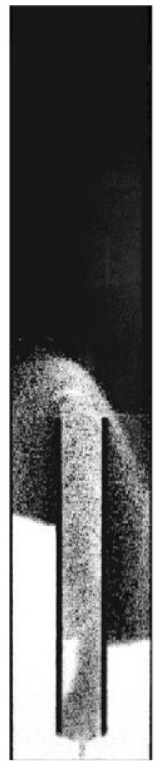

(c) $\mathrm{t}=3.5 \mathrm{~s}$

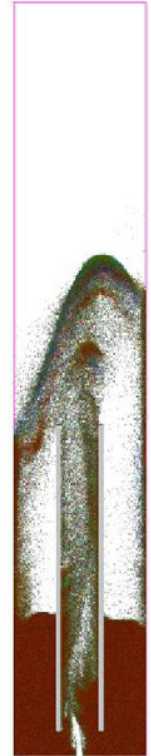

(d) $t=1 \mathrm{~s}$

simulation, the formation of particle clusters inside the draft plates is observed. These clusters partially block the draft plates and induce an unsteady pulsating flow with varying bed height. Furthermore, bubble formation was also observed in the annulus. Bubbles often propagate through the annulus in the form of slugs, due to the small width of the annulus. It is generally assumed that, the generation of slugs commences when the bubble size approaches $2 / 3$ of the bed width. It should be also noted that the particle circulation attributes to particle leaking from the bottom of the slugs in the downward direction.

\subsection{2. $\gamma$-Aluminum oxide particles (B4)}

The simulation results for $\gamma$-aluminum oxide particles are depicted in Fig. $10(\mathrm{~d}-\mathrm{g})$. It is observed that $\gamma$-aluminum oxide particles are transported to a lower height compared to glass particles. Furthermore,

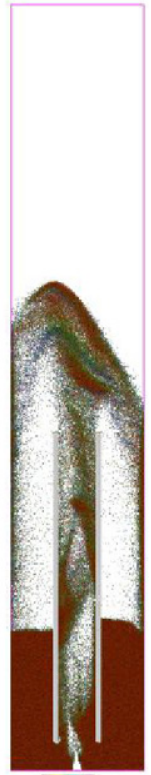

(e) $t=2 \mathrm{~s}$

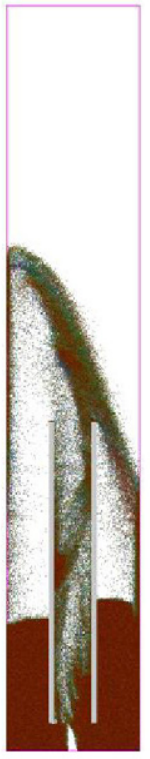

(f) $t=3 \mathrm{~s}$

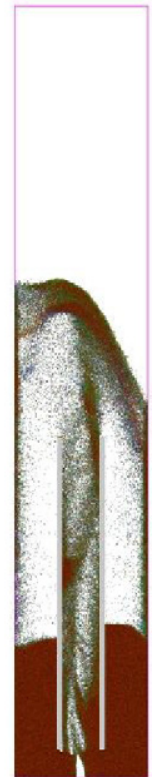

(g) $\mathrm{t}=7.5 \mathrm{~s}$

Fig. 8. Snapshots of spouting-with-aeration regime in a spout fluidized bed (a-c) experimental and (d-g) simulation results for $\gamma$-aluminum oxide particles (case B 3 ) 


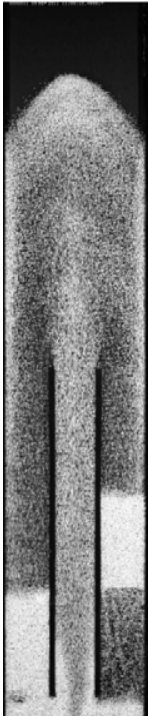

(a) $\mathrm{t}=1 \mathrm{~s}$

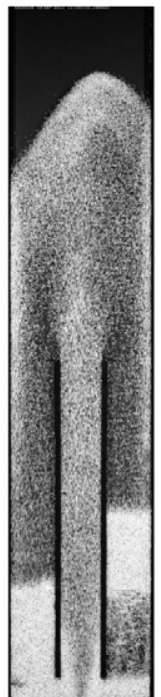

(b) $\mathrm{t}=2.5 \mathrm{~s}$

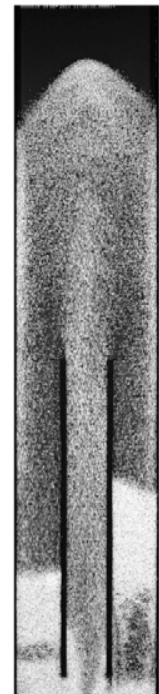

(c) $\mathrm{t}=3.5 \mathrm{~s}$

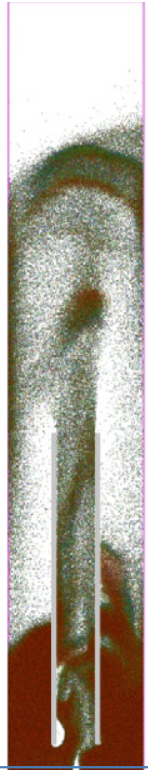

(d) $\mathrm{t}=1 \mathrm{~s}$

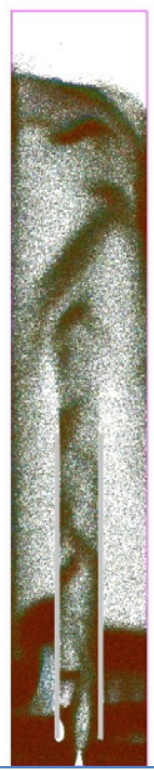

(e) $\mathrm{t}=2 \mathrm{~s}$

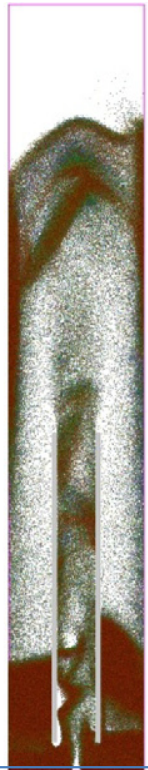

(f) $t=3 s$

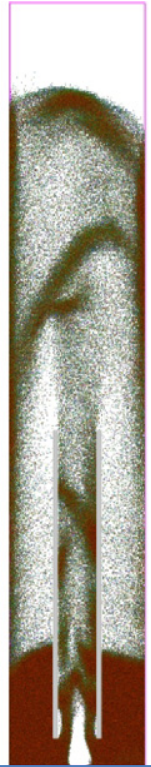

(g) $\mathrm{t}=7.5 \mathrm{~s}$

Fig. 9. Snapshots of fluidized bed-spouting-with-aeration regime in a spout fluidized bed (a-c) experimental and (d-g) simulation results for glass particles (case B2).

despite the higher background velocity, less pronounced particle movement was observed in the annulus with an unstable spout. This may be due to the change in the particle physical properties, especially the restitution coefficient. As the restitution coefficient decreases the energy dissipation rate during inter particle collisions increases, which leads to the formation of the dense regions that partially block the draft plates. This also causes higher gas bypassing through the annulus. Similar kind of flow patterns were observed in the experiments and simulations.

\subsection{Time-averaged particle velocity}

In Fig. 11 the time-averaged particle velocity profiles are presented and compared with the experimental data obtained from PIV measurements.
Fig. 11(a-b) shows the comparison for case B1 at various vertical positions and reveal good agreement between simulation and experiments, however in the annulus the agreement is less. This may be due to the exclusion of rolling friction in the model. Goniva et al. [26] reported that increasing the particle-particle and particle-wall rolling friction leads to lower downward particle velocities of the dense flow in the annulus without any pronounced effect on the particle velocity in the spout.

In addition, the jet emerging from the draft plates shows a small deflection to the right. For case B2, simulation results at a bed height $\mathrm{z}=30$ and $50 \mathrm{~cm}$ show a good agreement with the experimental data (see Fig. 11(c-d)). The obtained results show the slanting of the spout. This is mainly because particle clusters formations at various heights in draft plates. Also, cluster formation is more pronounced at lower background velocity.

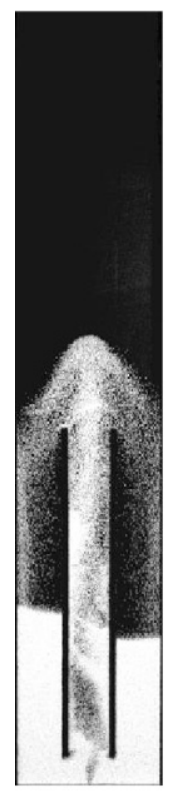

(a) $\mathrm{t}=1 \mathrm{~s}$

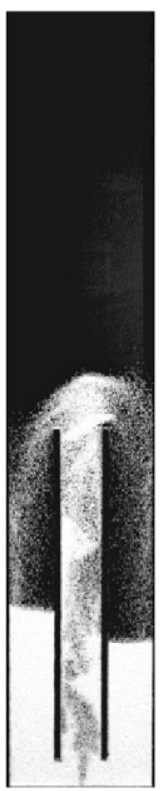

(b) $\mathrm{t}=2.5 \mathrm{~s}$

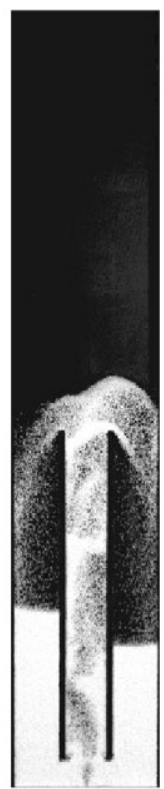

(c) $\mathrm{t}=3.5 \mathrm{~s}$

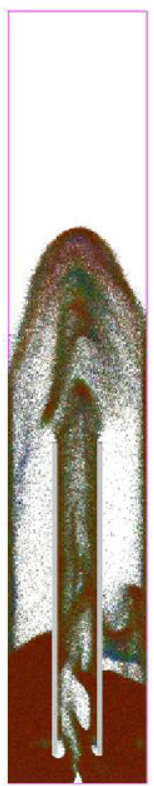

(d) $t=1 \mathrm{~s}$

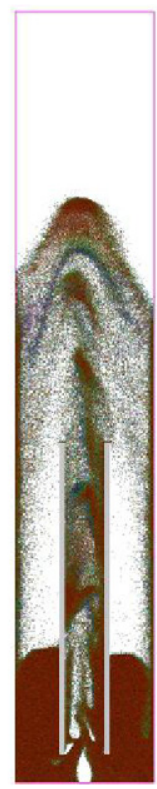

(e) $t=2 s$

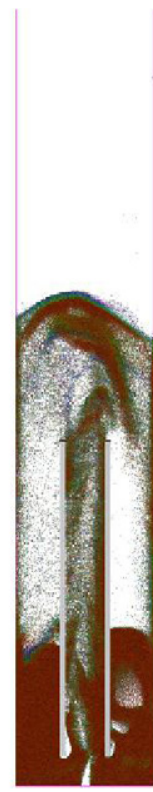

(f) $\mathrm{t}=3 \mathrm{~s}$

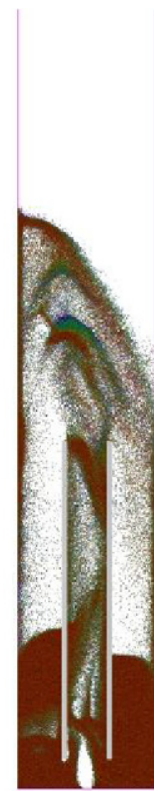

(g) $\mathrm{t}=7.5 \mathrm{~s}$

Fig. 10. Snapshots of fluidized bed-spouting-with-aeration regime in a spout fluidized bed (a-c) experimental and (d-g) simulation results for $\gamma$-aluminum oxide particles (case B 4). 
(a) $\mathrm{z}=30 \mathrm{~cm}$

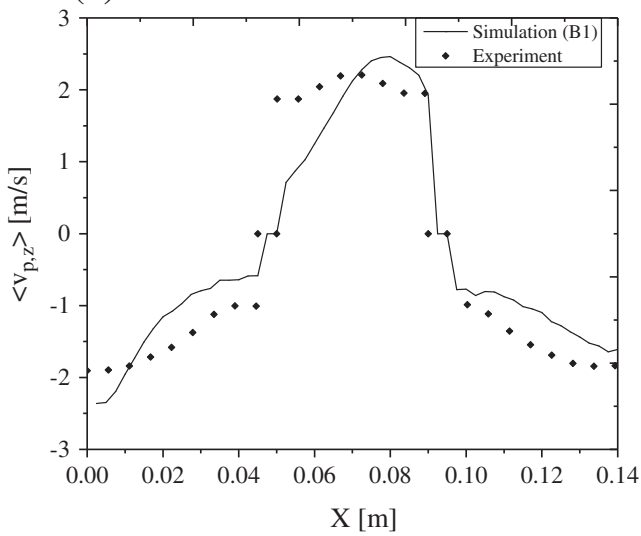

(c) $\mathrm{z}=30 \mathrm{~cm}$

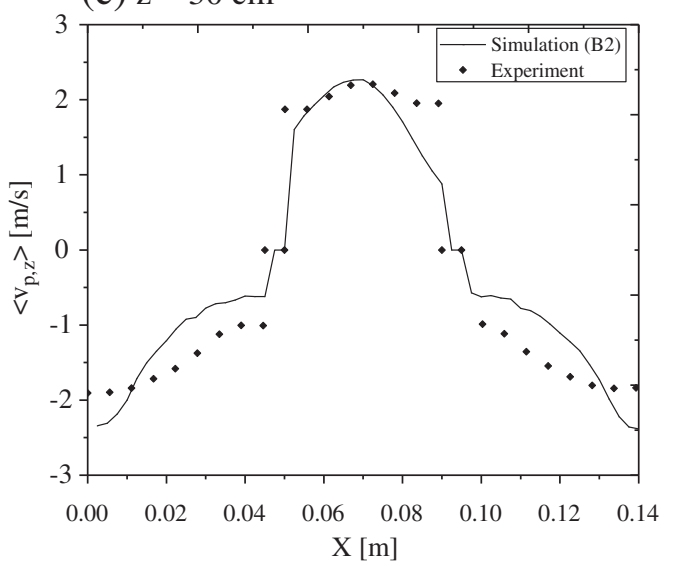

(b) $\mathrm{z}=50 \mathrm{~cm}$

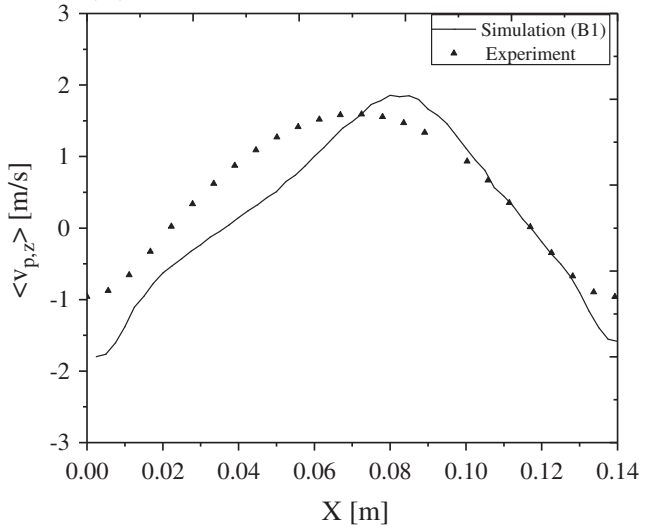

(d) $\mathrm{z}=50 \mathrm{~cm}$

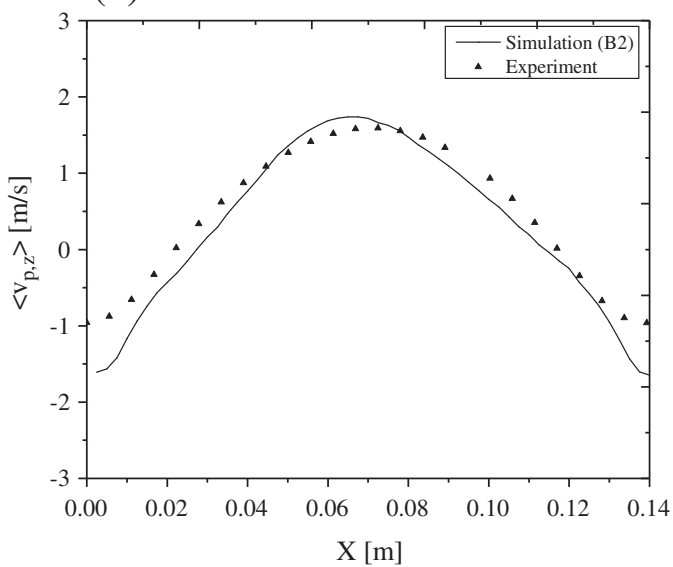

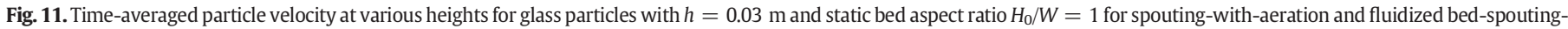
with-aeration (dispersed spout) for various simulations cases such as (a-b) case B1 and (c-d) case B2.

\section{Conclusions}

A flow regime map was constructed for a pseudo 2D spout fluidized bed with draft plates, by capturing the high-speed images and fast Fourier transformation (FFT) of measured pressure signals. In this study, eight distinct flow regimes were identified by changing the background velocity from 0 to $1.75 \mathrm{~m} / \mathrm{s}$ with increments of $0.25 \mathrm{~m} / \mathrm{s}$ and the spout velocity from 10 to $50 \mathrm{~m} / \mathrm{s}$ with increments of $5 \mathrm{~m} / \mathrm{s}$. With increasing spout velocity, particle circulation increases for the entire range of background velocities. At low background velocities, less pronounced particle motion was observed in the annulus. However, increasing the background velocities causes higher particle circulation rates through the fluidized annulus. Moreover, increasing the background velocity has a stabilizing effect on the particles in the annulus. In order to attain particle circulations at low background velocity, the spout velocity should be sufficiently high.

Simulations of a spout fluidized bed with draft plates were carried out by using a discrete particle model (DPM). In the DPM the dynamics of the gas phase is described by the volume averaged Navier-Stokes equations; whereas the motions of the individual particle were determined by Newton's laws of motion by considering a soft-sphere collision model. The draft plates in the spout fluidized bed were treated as internal walls.

Simulations were performed for two particulate systems, namely glass and $\gamma$-aluminum oxide by selecting two regimes, viz. spoutingwith-aeration and fluidized bed-spouting-with-aeration (dispersed spout). The obtained results in terms of flow patterns and timeaveraged particle velocities for glass and $\gamma$-aluminum oxide particles in both the regimes were compared with experimental results. These comparisons show good agreement. Better agreement in the annulus may be achieved by including a rolling friction model.

\section{List of symbols}

\begin{tabular}{lll}
\hline & Property & Unit \\
\hline Symbol & & \\
$a$ & Ratio of cube diameter to particle diameter & - \\
$c$ & V-SGS model constant & - \\
$C_{\mathrm{d}}$ & Drag coefficient & - \\
$C_{\mathrm{s}}$ & Smagorinsky constant & {$[\mathrm{m}]$} \\
$D$ & Depth of the bed & {$[\mathrm{m}]$} \\
$d_{\text {cube }}$ & Size of the cube & {$[\mathrm{m}]$} \\
$D_{s p}$ & Depth of the spout & {$[\mathrm{m}]$} \\
$D_{d t}$ & Depth of the draft plates & {$[\mathrm{m}]$} \\
$d_{p}$ & Diameter of the particle & - \\
$e_{n}$ & Normal restitution coefficient & - \\
$e_{t}$ & Coefficient of tangential restitution & - \\
$f_{j}^{\text {cube }}$ & Volume fraction of $j$ cell occupied by the cube & {$\left[\mathrm{m} / \mathrm{s}^{2}\right]$} \\
$\mathbf{g}$ & Acceleration due to gravity & {$[\mathrm{m}]$} \\
$h$ & Entrainment height & {$[\mathrm{m}]$} \\
$H$ & Height of the bed & {$[\mathrm{m}]$} \\
$H_{d t}$ & Height of the draft plates & {$[\mathrm{m}]$} \\
$H_{0}$ & Static height of the particle bed & - \\
$M$ & Image magnification & - \\
$M_{a v g}$ & Average molecular weight & - \\
$N_{p}$ & Number of particles & - \\
$k$ & Scaling factor & {$[\mathrm{N} / \mathrm{m}]$} \\
$k_{n}$ & Normal spring stiffness & {$[\mathrm{Pa}]$} \\
$p_{g}$ & Gas pressure & {$[\mathrm{J} /(\mathrm{mol} \cdot \mathrm{K})]$} \\
$R$ & Universal gas constant & {$[\mathrm{m}]$} \\
$R_{a}$ & Radius of the particle a & - \\
$S_{p}$ & Source term & {$[\mathrm{m}]$} \\
$\mathbf{s}_{p}$ & Volume average particle displacement & \\
\hline & & - \\
& & -
\end{tabular}


(continued)

\begin{tabular}{|c|c|c|}
\hline & Property & Unit \\
\hline$T$ & Temperature of gas & {$[\mathrm{K}]$} \\
\hline$\Delta t$ & Time interval & {$[s]$} \\
\hline$\Delta t_{p}$ & Time step for particle & [s] \\
\hline $\mathbf{T}_{p}$ & Torque on the particle & {$[\mathrm{Nm}]$} \\
\hline$\Delta t_{g}$ & Time step for gas & {$[\mathrm{s}]$} \\
\hline$u_{b g}$ & Background velocity & {$[\mathrm{m} / \mathrm{s}]$} \\
\hline$u_{m f}$ & Minimum fluidization velocity & {$[\mathrm{m} / \mathrm{s}]$} \\
\hline$u_{s p}$ & Spout velocity & {$[\mathrm{m} / \mathrm{s}]$} \\
\hline $\mathrm{v}_{p}$ & Volume average particle velocity & {$[\mathrm{m} / \mathrm{s}]$} \\
\hline W & Width of the bed & {$[\mathrm{m}]$} \\
\hline$W_{d t}$ & Width of the draft tube & {$[\mathrm{m}]$} \\
\hline$W_{s p}$ & Width of the spout & {$[\mathrm{m}]$} \\
\hline \multicolumn{3}{|c|}{ Greek letters } \\
\hline$\left\langle\mathrm{v}_{p, z}\right\rangle$ & Time-average particle velocity & {$[\mathrm{m} / \mathrm{s}]$} \\
\hline$\Delta x$ & Grid size in $\mathrm{x}$ direction & {$[\mathrm{m}]$} \\
\hline$\Delta y$ & Grid size in y direction & {$[\mathrm{m}]$} \\
\hline$\Delta z$ & Grid size in $\mathrm{z}$ direction & {$[\mathrm{m}]$} \\
\hline$\varepsilon_{g}$ & Gas volume fraction & - \\
\hline$\rho_{g}$ & Density of the gas & {$\left[\mathrm{kg} / \mathrm{m}^{3}\right]$} \\
\hline$\rho_{s}$ & Density of the solid & {$\left[\mathrm{kg} / \mathrm{m}^{3}\right]$} \\
\hline$\varepsilon_{\mathrm{s}}$ & Solid volume fraction & - \\
\hline$\beta$ & Momentum transfer coefficient & {$\left[\mathrm{kg} / \mathrm{m}^{3} \mathrm{~s}\right]$} \\
\hline$\delta$ & Distribution function & - \\
\hline$\omega_{p}$ & Angular velocity & {$[1 / \mathrm{s}]$} \\
\hline$\varepsilon_{\text {cube }}$ & Porosity of the cube & - \\
\hline$\phi_{E}$ & Variable on Eulerian grid & - \\
\hline$\phi_{L}$ & Variable on Lagrangian grid & - \\
\hline$\mu_{g}$ & Dynamic viscosity of the gas & {$[\mathrm{kg} / \mathrm{ms}]$} \\
\hline$\mu_{\text {tur }}$ & Shear induced turbulent viscosity & {$[\mathrm{kg} / \mathrm{ms}]$} \\
\hline$\Delta$ & Filter width & - \\
\hline$|\mathrm{S}|$ & Characteristic filtered strain & - \\
\hline$\alpha$ & $(3 \times 3)$ matrix of the derivatives of the filtered velocity $\mathbf{u}_{g}$ & - \\
\hline$\nu_{g}$ & Kinematic viscosity of gas & {$\left[\mathrm{m}^{2} / \mathrm{s}\right]$} \\
\hline
\end{tabular}

\section{Acknowledgments}

This research is supported by the Dutch Technology Foundation STW, applied science division of NWO and the Technology Program of the Ministry of Economic Affairs in The Netherlands, as well as by the DFG (German Research Foundation) in Germany.

\section{References}

[1] A. Chatterjee, Spout-fluid bed technique, Ind Eng Chem Process Des Dev 9 (1970) 340-341.

[2] J.M. Link, N.G. Deen, J.A.M. Kuipers, X. Fan, A. Ingram, D.J. Parker, et al., PEPT and discrete particle simulation study of spout-fluid bed regimes, AIChE J 54 (2008) 1189-1202.

[3] W. Zhong, Y. Xiong, Z. Yuan, M. Zhang, DEM simulation of gas-solid flow behaviors in spout-fluid bed, Chem Eng Sci 61 (2006) 1571-1584.

[4] B. Ren, W. Zhong, B. Jin, Z. Yuan, Y. Lu, Modelling of gas-particle turbulent flow in spout-fluid bed by computational fluid dynamics with discrete element method, Chem Eng Technol 34 (2011) 2059-2068.
[5] M.S. van Buijtenen, M.S. van Dijk, N.G. Deen, J.A.M. Kuipers, T. Leadbeater, D.J. Parker, Numerical and experimental study on multiple-spout fluidized beds, Chem Eng Sci 66 (2011) 2368-2376.

[6] M.S. van Buijtenen, K. Buist, N.G. Deen, J.A.M. Kuipers, T. Leadbeater, D.J. Parker, Numerical and experimental study on spout elevation in spout-fluidized beds, AIChE J 58 (2012) 2524-2535.

[7] T. Ishikura, H. Nagashima, M. Ide, Hydrodynamics of a spouted bed with a porous draft tube containing a small amount of finer particles, Powder Technol 131 (2003) 56-65.

[8] J.K. Claflin, A.G. Fane, Spouting with a porous draft-tube, Can J Chem Eng 61 (1983) 356-363.

[9] M.A. van der Hoef, M. van Sint Annaland, A.T. Andrews, S. Sundaresan, J.A.M. Kuipers, Multiscale modelling of gas-fluidized beds, Adv Chem Eng 31 (2008) 65-149.

[10] J. Link, C. Zeilstra, N. Deen, H. Kuipers, Validation of a discrete particle model in a 2D spout-fluid bed using non-intrusive optical measuring techniques, Can J Chem Eng 82 (2004) 30-36.

[11] J.M. Link, L.A. Cuypers, N.G. Deen, J.A.M. Kuipers, Flow regimes in a spout-fluid bed: a combined experimental and simulation study, Chem Eng Sci 60 (2005) 3425-3442.

[12] J.M. Link, W. Godlieb, P. Tripp, N.G. Deen, S. Heinrich, J.A.M. Kuipers, et al., Comparison of fibre optical measurements and discrete element simulations for the study of granulation in a spout fluidized bed, Powder Technol 189 (2009) 202-217.

[13] J.M. Link, W. Godlieb, N.G. Deen, J.A.M. Kuipers, Discrete element study of granulation in a spout-fluidized bed, Chem Eng Sci 62 (2007) 195-207.

[14] Z. Deng, R. Xiao, B. Jin, H. Huang, L. Shen, Q. Song, et al., Computational fluid dynamics modelling of coal gasification in a pressurized spout-fluid bed, Energy Fuel 22 (2008) 1560-1569.

[15] W. Zhong, M. Zhang, B. Jin, Z. Yuan, Flow behaviors of a large spout-fluid bed at high pressure and temperature by 3D simulation with kinetic theory of granular flow, Powder Technol 175 (2007) 90-103.

[16] Y. Zhang, B. Jin, W. Zhong, B. Ren, R. Xiao, DEM simulation of particle mixing in flat-bottom spout-fluid bed, Chem Eng Res Des 88 (2010) 757-771.

[17] M.S. van Buijtenen, N.G. Deen, S. Heinrich, S. Antonyuk, J.A.M. Kuipers, Discrete Particle simulation study on the influence of the restitution coefficient on spout fluidized-bed dynamics, Chem Eng Technol 32 (2009 a) 454-462.

[18] M.S. van Buijtenen, M. Börner, N.G. Deen, S. Heinrich, S. Antonyuk, J.A.M. Kuipers, An experimental study of the effect of collision properties on spout fluidized bed dynamics, Powder Technol 206 (2011 b) 139-148.

[19] H. Nagashima, T. Ishikura, M. Ide, Flow regimes and vertical solids conveying in a spout-fluid bed with a draft tube, Can J Chem Eng 9999 (2011) 1-10.

[20] R. Beetstra, M.A. van der Hoef, J.A.M. Kuipers, Drag force of intermediate Reynolds number flow past mono-and bidisperse arrays of spheres, AIChE J 53 (2007) 489-501.

[21] A. Vreman, An eddy-viscosity subgrid-scale model for turbulent shear flow: algebraic theory and applications, Phys Fluids 16 (2004) 3670-3681.

[22] J. Smagorinsky, General circulation experiments with the primitive equations, Mon Weather Rev 91 (1963) 99-164.

[23] B.P.B. Hoomans, J.A.M. Kuipers, W.J. Briels, W.P.M. van Swaaij, Discrete particle simulation of bubble and slug formation in a two-dimensional gas-fluidised bed: a hard-sphere approach, Chem Eng Sci 51 (1996) 99-118.

[24] N.G. Deen, M. van Sint Annaland, J.A.M. Kuipers, Multi-scale modelling of dispersed gas-liquid two-phase flow, Chem Eng Sci 59 (2004) 1853-1861.

[25] J.M. Link, Development and Validation of a Discrete Particle Model of a Spout-Fluid Bed Granulator, PhD thesis University of Twente, The Netherlands, 2006.

[26] C. Goniva, C. Kloss, N.G. Deen, J.A.M. Kuipers, S. Pirker, Influence of rolling friction on single spout fluidized bed simulation, Particuology 10 (2012) 582-591.

[27] Q. Xiong, L. Deng, W. Wang, W. Ge, SPH method for two-fluid modeling of particle-fluid fluidization, Chem Eng Sci 66 (2011) 1859-1865. 